\title{
EDITORIAL
}

\section{The MLI in Action}

1. This Intertax issue focuses on some of the most controversial themes raised by the Multilateral Convention to Implement Tax Treaty Related Measures to Prevent BEPS (the Multilateral Instrument (MLI)). ${ }^{1}$ The MLI was a multilateral response to implement BEPS 1.0 measures which consequently requires changes to tax treaties. ${ }^{2}$

Four years have elapsed since the MLI was signed (7 June 2017). Whereas the international tax system is currently under discussion from its very fundament (which is referred to as BEPS 2.0), ${ }^{3}$ the papers published below examine some of the regimes approved by the MLI and illustrate problems, inconsistencies, or insufficiencies in those regimes.

Like it or not, the ongoing reform of the international tax system is not expected to overrule the OECD Model Convention, the MLI, and the current allocation of taxing rights but to add complexity to it. Meanwhile, lawyers are expected to understand and face the challenges raised by the MLI and its relationship with covered tax agreements (CTAs) and national tax legislation.

Intertax contributions that are dedicated to the implementation of the MLI assist the reader in understanding the challenges raised by it. The papers focus on the MLI rules in action, looking back to the past and forward to the future, and seek new angles of legal and policy analysis.

2. In 'A Plea for a Workforce Presence Permanent Establishment Concept in a Post-Covid Digitalized World', Svetislav Kostić focuses attention on remote work as a variable that is neither caught by the permanent establishment rules (the old rules or the MLI rules) ${ }^{5}$ nor by the Blueprint on Pillar One. ${ }^{6}$ Two examples proposed by the author illustrate the relevance of the stateless income generated by the workforce:

Example One:

Digital enterprise E, resident in State A, maintains most of its workforce in State $\mathrm{C}$ where E's product or service is developed, provided, and maintained. ${ }^{7}$ The current rules and the Blueprint on Pillar One would grant taxing rights to State $\mathrm{A}$ as the residence state and to the states acting as market jurisdictions. However, the workforce would not constitute per se a permanent establishment that is encompassed by the current rules and, therefore, State $C$ would not be entitled to tax.

Example Two:

Digital enterprise E resident in State A generates profits from customers/users in State B without having any physical presence in that state. E has basic supporting facilities in A while the vast majority of

\section{Notes}

OECD, Multilateral Convention to Implement Tax Treaty Related Measures to Prevent Base Erosion and Profit Shifting (2017), https://www.oecd.org/tax/treaties/multilateralconvention-to-implement-tax-treaty-related-measures-to-prevent-BEPS.pdf (accessed 5 July 2021).

See A. P. Dourado, International Tax Multilateralism or Reinforced Unilateralism?, in International and EU Tax Multilateralism: Challenges Raised by the MLI, GREIT Series, 1-14 (A. P. Dourado ed., IBFD 2020) and all the other chapters therein.

OECD, Tax Challenges Arising from Digitalisation - Report on Pillar One Blueprint, Inclusive Framework on BEPS, https://www.oecd.org/tax/beps/tax-challenges-arising-fromdigitalisation-report-on-pillar-one-blueprint-beba0634-en.htm (accessed 5 July 2021); OECD/G20, Tax Challenges Arising from Digitalisation - Report on Pillar Two Blueprint Inclusive Framework on BEPS, https://www.oecd.org/tax/beps/tax-challenges-arising-from-digitalisation-report-on-pillar-two-blueprint.pdf (accessed 5 July 2021).

In this issue: S. V. Kostić, A Plea for a Workforce Presence PE Concept in a Post-COVID Digitalised World, 49(10) Intertax (2021).

OECD, Model Tax Convention on Income and on Capital, Full Version (as read on 21 November 2017) (OECD Publishing 2017), https://read.oecd-ilibrary.org/taxation/model-taxconvention-on-income-and-on-capital-2017-full-version_g2g972ee-en\#page1 (accessed 5 July 2021); and OECD, supra n. 1.

6 OECD, Tax Challenges Arising from Digitalisation - Report on Pillar One Blueprint, Inclusive Framework on BEPS, OECD/G20 Base Erosion and Profit Shifting Project (OECD Publishing 2020), https://www.oecd.org/tax/beps/tax-challenges-arising-from-digitalisation-report-on-pillar-one-blueprint-beba0634-en.htm (accessed 5 July 2021).

Kostić, supra n. 4, para. 5 . 
the workforce is located throughout the world. The workforce of $\mathrm{E}$ is engaged by virtues of service contracts or platforms, use their own laptops, and partially rely on E's software using premises that are not at the disposal of E. ${ }^{8}$

In these examples, there is no permanent establishment in the states of the workforce. The author relies on the premise that allocation of taxing rights to the triangle residence, source, and market states is justifiable in light of the digitalized economy.

Departing from the current reality, Kostić intends to demonstrate that people's functions are still at the core of the economy and that both the MLI and BEPS 2.0 ignore its relevance to a great extent.

Kostić refers to freelance remote work as the new normal and invokes Ukraine, Pakistan, and the Philippines as the world leaders in this type work, and it will likely continue to increase in the postpandemic economy. Kostić emphasizes that remote work has led to a new category of 'independent workers' with no labour rights or social security.

Thus, source, as the place of business, re-emerges as the place of work. However, remote work will not be held to be a permanent establishment under the current rules. Elaborating on the examples summarized above, the author claims that both the current and the future international tax system need a concept of permanent establishment that must include the place where the workforce is located. This subsequently requires a new concept of permanent establishment. As a corollary, the source state, corresponding to the state of the permanent establishment and covering the workforce, is to be granted taxing rights. International coordination would allow that the states of work are entitled to income taxes and social security revenues. ${ }^{10}$

3. Andrés Báez Moreno's article is titled 'How do "the old" and "the new" live together? ${ }^{11}$ The principal purpose test and other anti-avoidance instruments in tax treaties'. It focuses on the interpretation of the MLI general anti-avoidance rule (the principal purpose test (PPT) rule) and, more specifically, on its interaction with other anti-avoidance rules.

Báez Moreno recognizes the (apparent) usefulness of the PPT rule since, previous to the MLI, there was no systematic response to treaty abuse in the OECD Model Convention. The massive incorporation of the PPT rule into tax treaties is also a sign of success.

In spite of its apparent usefulness, Báez Moreno first holds that the PPT rule, as drafted, has been the most inferior of all of the options. According to the author, this is due to its indeterminacy and to the consequences in the event that it is applicable. If there is treaty abuse, there will be no entitlement to treaty benefits which is a harsh consequence not finding an equivalent in other anti-avoidance rules. ${ }^{12}$

However, the main problem lies in the relationship between the PPT rule, other CTA's anti-avoidance rules, and domestic anti-avoidance rules: There are a few provisions attempting to clarify this interaction, however, they do not solve most of the problems. ${ }^{13}$

The author first recalls Article 7 paragraph 2, of the MLI. This rule clarifies that the PPT replaces existing provisions of the CTA that deny all or part of the benefits otherwise provided under the CTA. Moreover, according to BEPS Action 6 final report, and the 2017 OECD Model Convention commentaries, a person entitled to treaty benefits under the limitation-on-benefits clause can be denied those benefits under the PPT rule. ${ }^{14}$

By proposing some examples, Báez Moreno illustrates how the application conflicts between treaty rules and national rules, general anti-avoidance rules, targeted anti-avoidance rules, and special anti-avoidance rules are not resolved by the classical legal principles: international law prevailing over national law; subsequent agreement to the CTA in the meaning of Article 31(3)(b) of the Vienna Convention on the Law of Treaties; lex posterior derogat lex anterior; lex specialis derogat legi generali; and contextual interpretation. ${ }^{15}$

\section{Notes}

Ibid.

Ibid.

Ibid., para. 6.

11 In this issue: A. Báez Moreno, How Do 'the Old' and 'the New' Live Together? The Principal Purpose Test and Other Anti-avoidance Instruments in Tax Treaties, 49(10) Intertax (2021).

12 Ibid., para. 2.

13 Ibid.

14 Ibid.

15 See also R. Szudoczky \& D, Blum, Unveiling the MLI: An Analysis of Its Nature, Relationship to Covered Tax Agreements and Interpretation in Ligbt of the Obligations of Its Parties, in International and EU Tax Multilateralism: Challenges Raised by the MLI, GREIT Series, 125-160 (A. P. Dourado ed., IBFD 2020); R. Prokisch \& F. Souza de Man, 
This is because the rules are drafted differently, providing for a variety of conditions of application, foreseeing dissimilar situations, and leading to distinct consequences. For example, whereas General Anti-Avoidance Rules (GAARs) lead to the replacement of the avoidance scheme pattern by a nonavoidance one, the PPT implies the loss of treaty benefits. Since the scope of the assortment of antiavoidance rules is different, the relationship among the entire number of anti-avoidance rules becomes indistinct and uncertain.

Báez Moreno draws special attention to the beneficial ownership clauses in Articles 10 to 12 OECD Model Convention and elaborates on the relationship between the PPT rule and the clauses mentioned previously. ${ }^{16} \mathrm{He}$ recalls that the meaning of beneficial ownership clauses is more ambiguous and undetermined than the vague conditions underlying the PPT rule. He criticizes the fact that they are being used as GAARs. According to the author, these features and practice also imply a difficult compatibilization with the PPT rule. Ultimately, Báez Moreno is more critical of the existence of the beneficial ownership clauses (and their non-removal by the MLI) than the PPT rule.

4. In his article, 'Hybrid Entity Mismatches and the MLI: A Tax Policy Assessment' Leopoldo Parada $^{17}$ assesses the tax policy implications of the two types of provisions in relation to hybrid entity mismatches provided for by the MLI. The first type is a provision that helps to answer the question of who is entitled to the benefits of a tax treaty in those cases when income is received by or through a tax transparent entity (Article 3(1) of the MLI). The second type is a provision usually referred to as the saving clause that aims to protect a contracting state's right to tax their own residents regardless of the limitations of the treaty (Articles 11 and 3(3) of the MLI).

Parada initially illustrates the lack of cohesion with the main and traditional objective of tax treaties. He specifically addresses the avoidance of double taxation in circumstances when the new MLI provision on tax treaty entitlement interacts with the provisions of the saving clause protecting the rights of source states to tax their own residents. The result is unrelieved double taxation. ${ }^{18}$

Secondly, he proceeds to argue that the MLI not only failed to maintain cohesion with the traditional tax treaty objective of avoiding double taxation but has also reinforced a more unequal distribution of taxing powers between residence and source states. Such a position is based on the results emanating from the interaction between the new MLI provision on tax treaty entitlement and a number of specific allocative rules within treaties, particularly Articles 10, 11, and 12 OECD MC and the beneficial ownership requirement. ${ }^{19}$

Thus, Parada concludes that from a tax policy perspective and strictly related to the dynamic of granting/denying tax treaty benefits in cases involving hybrid entity mismatches, the MLI has not been a success. Adhering to the principles of cohesion and equality in the distribution of taxing powers within tax treaties but also aiming to add certainty and simplicity to the interpretation of the MLI and the issues related to hybrid entity mismatches, the author provides a detailed proposal on the introduction of three alternative rules (1) a 'reverse saving clause', (2) an enhanced (deemed) beneficial owner rule and (3) coordination of entities' classification rule within the MLI. The proposed measures can be simultaneously applied as they address different concerns, although the scope of the first two (reverse saving clause and the enhanced beneficial owner rule) is considerably reduced if the coordination rule is implemented.

Leopoldo Parada leaves the message that further work in the area of international taxation, particularly that relying on the MLI framework, should not be limited to devising mere instruments to simplify the modification of bilateral tax treaties worldwide. Instead, there should be an attempt to introduce true multilateral-coordination instruments.

5. As only Article 17 of the MLI - envisaging a corresponding adjustment clause - refers explicitly to transfer pricing matters, the initial conclusion of most tax professionals is that the MLI is not

\section{Notes}

Multilateralism and International Tax Law: The Interpretation of Tax Treaties in Light of the Multilateral Instrument International and EU Tax Multilateralism: Challenges Raised by the MLI, GREIT Series, 199-226 (A. P. Dourado ed., IBFD 2020).

16 Moreno, supra n. 11, para. 2.

17 In this issue: L. Parada, Hybrid Entity Mismatches and the MLI: A Tax Policy Assessment, 49(10) Intertax (2021).

18 Ibid.

19 Ibid. 
particularly relevant concerning the problem of related party transactions' taxation. Stated otherwise, the BEPS Project's impact on this area of tax law is reflected within the 2017 revision of the OECD Transfer Pricing Guidelines and not in the provisions of the MLI.

The article 'The Multilateral Instrument (MLI) and Transfer Pricing' by Aitor Navarro ${ }^{20}$ demonstrate that the initial conclusion may be far from correct. He shows that the MLI actually has a relevant impact on tax treaty measures concerning transfer pricing and the arm's length principle. Navarro substantiates his position on the basis of a thorough analysis of the incidence of five MLI provisions on transfer pricing that pose significantly interrelated issues. These are, specifically, the saving clause of Article 11(1) of the MLI; the preamble enclosed in Article 6(1) of the MLI expressing the will to eliminate double taxation without creating opportunities for reduced taxation through tax evasion or avoidance enshrined in the PPT of Article 7(1) of the MLI; the corresponding adjustment provision of Article 17(1) of the MLI; and the mutual agreement provisions envisaged in Article 16 of the MLI. ${ }^{21}$

The author shows that a potential consequence of adopting the saving clause would be to render Article 9(1) of the OECD MC a merely declarative provision that is deprived of any meaningful content. Furthermore, the OECD Pillar I and Pillar II initiatives, with their impact on the integrity of the Arm's Length Principle (ALP) in correlation with the saving clause, may additionally raise issues in relation to the application of Article 9(1) of the OECD MC.

Navarro reiterates that the tax authorities and courts of several countries have approached transfer pricing from an anti-abuse angle with the outcome of enforcement of transfer pricing regulations beyond the ALP rationale. ${ }^{22}$ As a result, the inclusion of the preamble provided in Article 6(1) of the MLI could be used as a legitimation of such an approach, i.e., to consider that Article 9(1) of the OECD MC does not limit the applicability of domestic transfer pricing regulations beyond the ALP in a case of abuse. Additionally, the preamble could lead the tax authorities of the state where the counterpart is resident to deny the elimination of economic double taxation through a corresponding adjustment, if applicable. ${ }^{23}$

Article 17(1) of the MLI incorporates a corresponding adjustment mechanism to eliminate the economic double taxation that results from transfer pricing upward adjustments on profits. However, it should be remembered that Article 17(1) of the MLI presents certain issues regarding its compatibility with tax treaty clauses that do not mimic its content. It also does not resolve existing interpretation concerns raised by Article 9(2) of the OECD MC. ${ }^{24}$

Finally, Navarro analyses the relevance of Articles 16 (1) to (3) of the MLI, dealing with a Mutual Agreement Procedure (MAP), on transfer pricing cases and recognizes instances in which transfer pricing issues may still fall beyond the scope of a MAP even under the MLI. ${ }^{25}$

6. In their article 'The Influence of the BEPS Multilateral Instrument on Tax Treaties Concluded by Non-Signatory Countries,' ${ }^{26}$ Luís Eduardo Schoueri and Ramon Tomazela take on a highly interesting task of assessing the impact of the MLI on tax treaties concluded by non-signatory jurisdictions that have opted to be a part of the Inclusive Framework. In order to accomplish this goal, the authors focus on tax treaties signed or amended by such non-signatory countries after 2017, narrowing down the scope of their research to the following countries: Angola, Botswana, Brazil, Cape Verde, Congo, Maldives, Thailand, and Vietnam. In this context, Schoueri and Tomazela examine the tax treaty-related BEPS measures that were adopted by these countries in their bilateral tax treaties, addressing the merits and potential consequences of the choices made by non-signatory jurisdictions. ${ }^{27}$

The authors correctly recognize the existence of two basic questions that must be addressed. Firstly, there is the issue of why some jurisdictions decide to refrain from employing one of the most significant

\section{Notes}

20 In this issue: A. Navarro, The Multilateral Instrument (MLI) and Transfer Pricing, 49(10) Intertax (2021).

21 Ibid., para. 1

22 Ibid., para. 2.2.

23 Ibid.

24 Ibid., para. 3.1.

25 Ibid., para. 3.2

26 in this issue: L. E. Schoueri \& R. Tomazela, The Influence of the BEPS Multilateral Instrument on Tax Treaties Concluded by Non-Signatory Countries, 49(10) Intertax (2021).

27 Ibid., para. 1. 
international taxation instruments in history. Secondly, what is their attitude towards various solutions provided by the MLI. ${ }^{28}$

With respect to the first question, the authors notice that states that have invested significant effort and time in developing an independent and tailored tax treaty policy and a corresponding treaty network are hesitant to relinquish their achieved results and the freedom to continue in the same manner. $^{29}$

Regarding the second one, the meticulous research of Schoueri and Tomazela shows the general reasons for departing from the MLI provisions: (1) disagreement in relation to the solution provided for in the MLI with the adoption of different terminology that is suitable to achieve the same results with less questionable means; (2) the unclear economic effect of the BEPS tax measure; (3) the desire to implement a certain tax treatyrelated BEPS measure only in respect of some tax treaties and not others; (4) the existence of a similar provision in the tax treaty that is sufficient to counteract the specific abuse addressed by the provision of the MLI; (5) the MLI provision targets a type of abuse that is not relevant to a specific jurisdiction.

Bearing these in mind, the authors demonstrate that the impact of the MLI has been rather modest on treaty policy and treaties of non-signatory countries that have, at times, used certain MLI provisions, such as the PPT, only as a starting point and developing it further in accordance with their own needs and objectives. Some countries have exploited the implementation of the MLI as a renegotiation opportunity or, more precisely, an excuse to include other, non-MLI provisions. These include new provisions in their bilateral tax treaties on fees from technical services by the source state, income from hydrocarbons, and gains derived from corporate reorganizations.

The authors conclude with a cautionary note that failure to outrightly embrace multilateral efforts and proposals does not mean the complete rejection of a multilateral approach to solving international taxation issues. However, due care must be taken to ensure that, if tabled, such a proposal takes into account all vested interests and is diligently prepared. $^{30}$ In this respect, the work of Schoueri and Tomazela provides an excellent basis for future developments.

Ana Paula Dourado

Editor-in-Chief

Svetislav Kostic

Associate Professor at the University of Belgrade Faculty

of Law

Email:skostic@ius.bg.ac.rs.

\section{Notes}

28 Ibid.

29 Ibid., para. 6.

30 Ibid. 